\title{
最高裁判所の建築工事における二, 三の試験について
}

\author{
木 村 定 雄*
}

\begin{abstract}
梗 概 最高裁判所の庁舎新営工事はその規模において最近屈指の建築である。その大きさ，量 の多さのため施工に先立って各種の試験が行なわれた。そのうちより下記について報告する。 「架構模型による強度実験」

「場所打ちコンクリートぐいの載荷試験」

「同上くいの水平交番載荷試験」

キーワード : 共通実験・試験, 鉄筋コンクリート, 管理, 構造計画, 終局強さ, 安全率, 繰返し荷 重, [架構模型による強度実験] 建築物, 模型実験, [場所打ちコンクリートぐいの載荷試験, 同くい の水平交番試験] ぐい, 現場実験, 鉛直荷重, 水平荷重
\end{abstract}

1.まえがき

三宅坂に最高裁判所の庁舎が完成して次第に落着いた 姿を見せて来たこのごろである。

振返ってみると, 昭和 46 年 6 月に着工して昭和 49 年 3 月に完工寸るまで多くの人がいろいろな苦労をした 現場であった。設計者は公開設計競技で当選した岡田新 一設計事務所であり, 当選以来, 基本設計, 実施設計, 更に現場で設計施工管理を受持つ経過となった。建築の 施工者は鹿島建設であった。加えて建設省が総括管理者

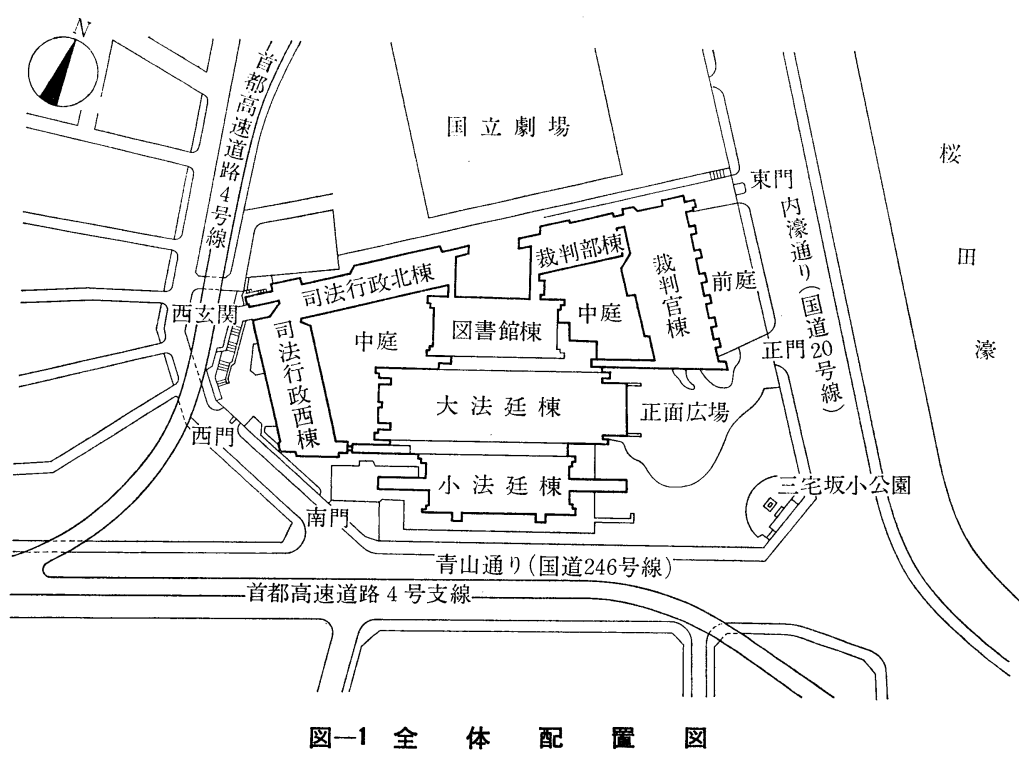

* 建設大臣官房官庁営繥部監督課 課長補佐
としての立場にあった。工事の進行はこの三者の合議の 形態で進められ，合議の結果現場構成員の力に余ること はそれぞれのバックの力, すなわち建設省官庁営縡部, 建設省建築研究所, 武藤構造力学研究所, 鹿島建設技術 研究所の指導, 助言, 実験による応援を得て解決してい った。以下に報告する項目は，いずれもこのようにして 得られた現場記録より選んだものである。

項目は「架構模型による強度実験」「場所打ちコンク リートぐいの載荷実験」,「場所打ちコンクリートぐいの 水平交番載荷試験」についてである。なお報告は現場記 録が主であり，結論にいたる考察は省略しているので了 承されたい。

\section{2. 架構模型による強 度試験}

\section{1 実験の対象と目的}

配置図（図一1）に示すよう に, 本庁舎は 7 棟より成立して いる。なかでも大法廷棟は名目 上機能上より中心となる存在で ある。この建物は当初より設計 上のポイントの一つであって実 施にあたって更にデザインで強 調されているところである。す なわち天空光を取入れたホー ル, 大法廷のスペースデザイン 


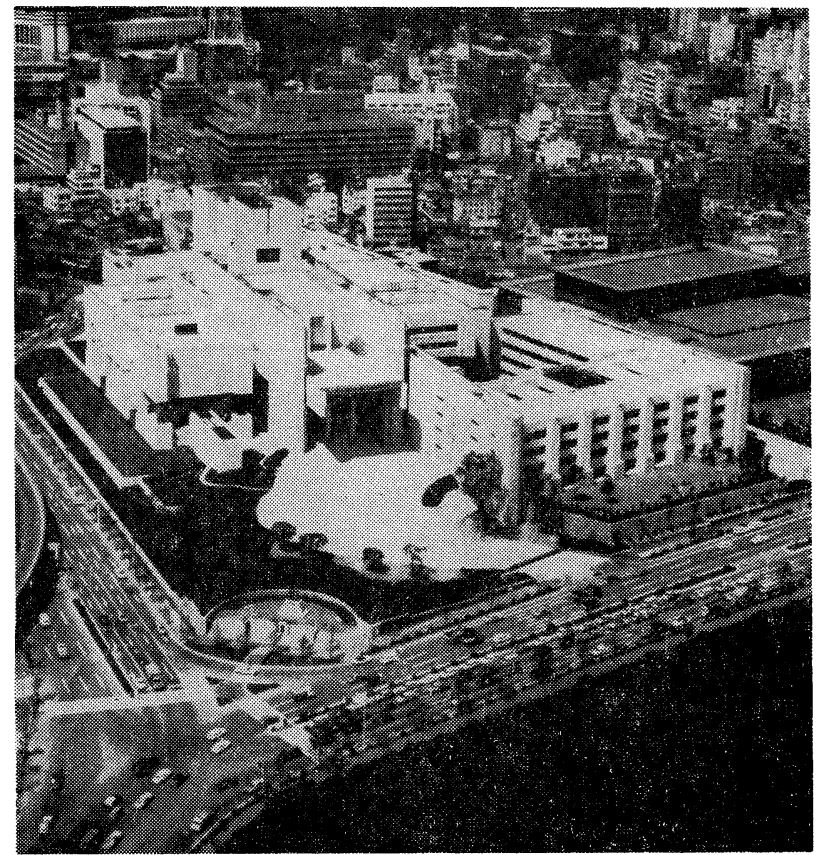

写真-1 全景 三差路は三宅坂, 右は半蔵門,

左は赤坂見附，左の黑っぽい建物は国立劇場

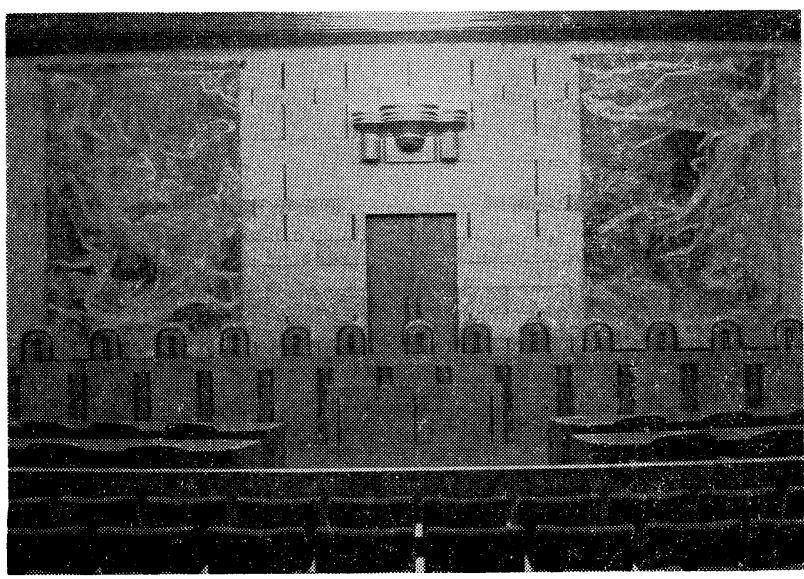

写真一2 大法廷 傍聴人席より裁判長席を見る
は，この建物を「法」の象徽的中心にと希求した 設計者の意図を示している。

これを構造デザインよりみると，平面図（図一 2）に示すようにホールと大法廷を鉄筋コンクリ 一下造の壁柱で囲んだ構成になっており，水平力 に対しては長手方向 $\mathrm{AB}, \mathrm{EF}$ の 2 列のコリドー ル，短手方向 4 列の壁柱により支持するデザイン となっている。このなかでも特に短手方向第 12 列 のラーメンは, 静的解析 (ベースシアー係数 0.6), 動的解析（最大加速度 $330 \mathrm{gal}$ ) を行なった結果 次のことがわかった架構である。

（1）全体のせん断力の約 $1 / 3$ を負担してい る。

（2）両側の壁柱, 大ばり, 基礎ばりのせん断



写真一3 ホール 正面に見えるバルコンをもった 壁が第 12 列ラーメンである。天井左右 より天空光が入っている。

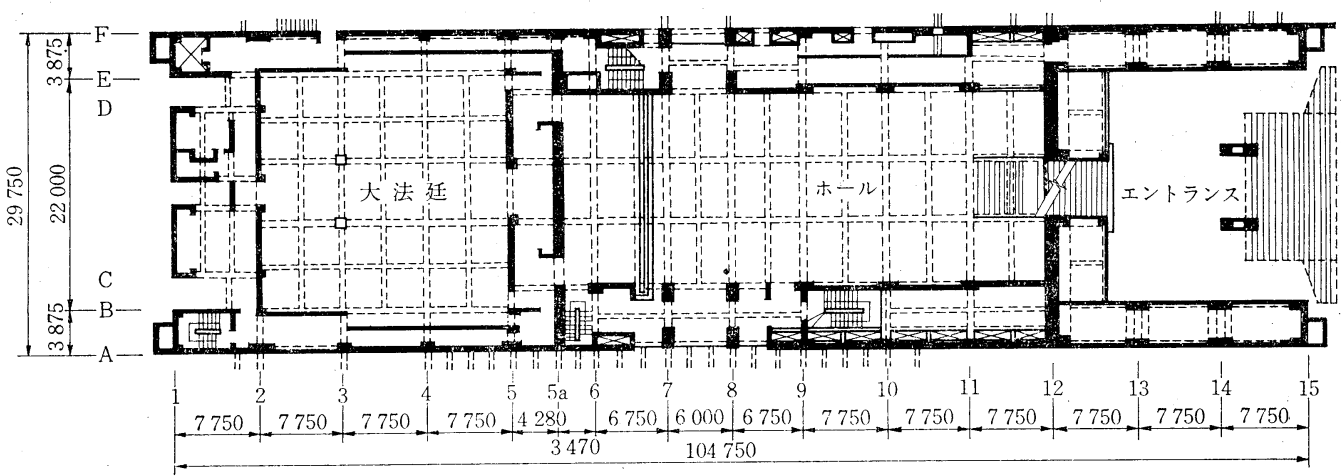

図一2 大法廷棟平面図 
表-1 実建物と供試体との対比

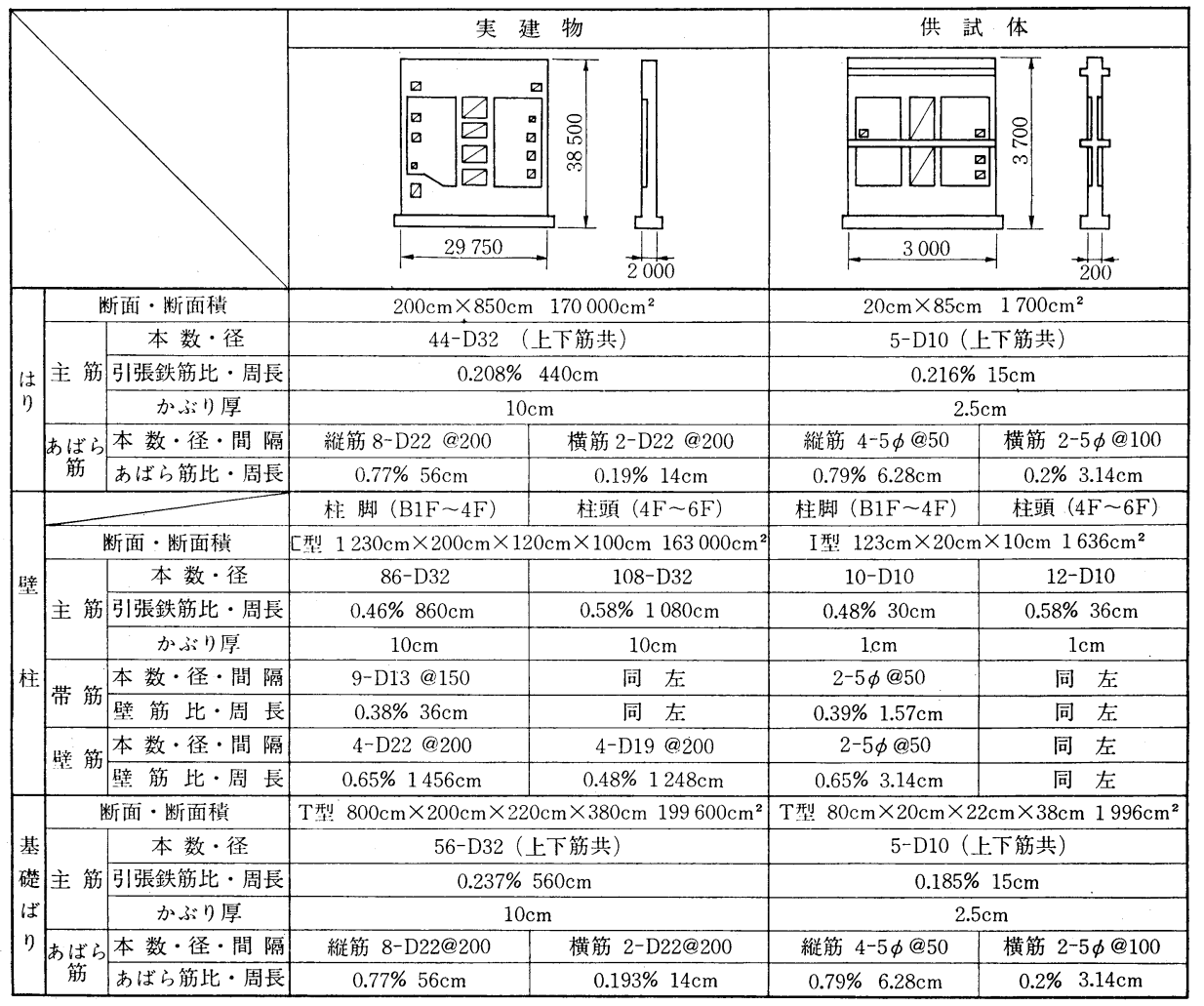

表一2 鉄筋の機械的性質

\begin{tabular}{|c|c|c|c|c|c|c|c|c|c|}
\hline \multirow{2}{*}{\multicolumn{2}{|c|}{ 種別 }} & \multicolumn{4}{|c|}{ 主 筋 SD 35 D 10} & \multicolumn{4}{|c|}{ 壁筋 (ワイヤメッシュ) せん断補強筋 $5 \phi$} \\
\hline & & 1 & 2 & 3 & 平 均 & 1 & 2 & 3 & 平 均 \\
\hline 径 $(\mathrm{mm})$ & & $\longrightarrow$ & - & - & $\begin{array}{l}\text { 公称 } \\
10.0\end{array}$ & 4.97 & 4.93 & 4.92 & 4.94 \\
\hline 面 & 積 $\left(\mathrm{cm}^{2}\right)$ & - & - & - & $\begin{array}{l}\text { 公称 } \\
0.71\end{array}$ & 0.19 & 0.19 & 0.19 & 0.19 \\
\hline 降 伏 応 力 & 度 $\left(\mathrm{t} / \mathrm{cm}^{2}\right)$ & 3.87 & 3.92 & - & 3.90 & 3.84 & 3.95 & - & 3.90 \\
\hline 破 断 応 力 & 度 $\left(\mathrm{t} / \mathrm{cm}^{2}\right)$ & 6.34 & 6.42 & - & 6.38 & 4.12 & 4.33 & 4.20 & 4.22 \\
\hline 弾 性 係 & 数 $\left(\mathrm{kg} / \mathrm{cm}^{2}\right)$ & 1.98 & 1.98 & 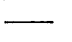 & $2.0 \times 10^{6}$ & 1.98 & 2.05 & 2.07 & $2.03 \times 10^{6}$ \\
\hline 降伏ひずみ & 度 (\%) & 0.195 & 0.198 & $\longrightarrow$ & 0.20 & 0.21 & 0.21 & - & 0.21 \\
\hline
\end{tabular}

応力度は, ほぼ同時に $\bar{\tau}=20 \mathrm{~kg} / \mathrm{cm}^{2}$ に達する。

（3）この架構は, 全体構造の critical point であ る。

このようなことより, 追試的な意味で本架構の模型を 作って強度実験を行ならことになった。

実験は, 第 12 列ラーメンに地震力の加わった場合の 力学的特性 (変形性状, 復元力特性, 耐力等) 確認し, あわせて施工上必要な指針があればそれを得るために行 なわれた。

\section{2 供 試 体}

供試体は実物と同じく鉄筋コンクリート造（川砂，豆
砂利コンクリート, 強度は実物 と同じく $F_{28}=225 \mathrm{~kg} /$ $\mathrm{cm}^{2}$ ) で，1/10 の縮尺である。実物および模型の寸法,

配筋は 表一1 に示すとおりである。

実物を供試体に縮小するときには，地震時に実物に生 ずる重要な応力状態を再現できることを目標として若干 形状を変えている。以下にその概要を記すと,

\section{（1）はり，床版，小開口の簡略化}

実物には各階の床版が両面についており，中央の大開 口にも各階にはりがある。また壁柱には廊下の開口の他 に点検用の小開口が所々に設けられている。これらの床 版, はり，小開口（十分に補強されている）を無視して も, 本ラーメンの力学的特性に不利に影響しないと考え られるので, これらを簡略化した。 


\section{（2） 配筋の簡略化}

実物の鉄筋径，間隔，かぶり厚さ等をそのまま $1 / 10$ にするのは供試体製作上困難である。このため供試体の 配筋は鉄筋比を実物と等しくなるようにした。

（3）加力用スラブの設置

供試体への加力はオイルジャッキ $(200 \mathrm{t}-2$ 連, 2 対, 片側反力壁片側テンションバー使用）で行なった が, 全荷重が一方の壁柱に集中して加わることを避ける ために加力用スラブをを設けた。このスラブによって往 復の加力は, 加力と反対側の壁柱にも等しく伝わること を期待した。加力用スラブは供試体と縁を切って作ら れ, 鋼棒で結ばれている。

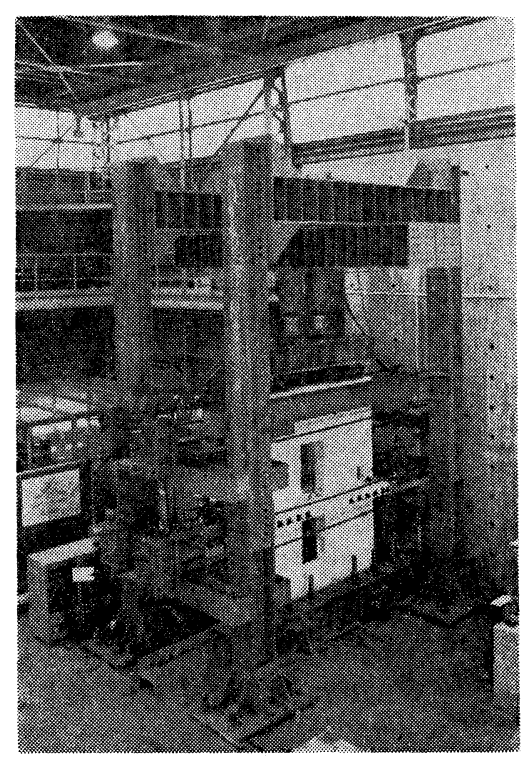

写真一4 架構模型による強度実験（全景）

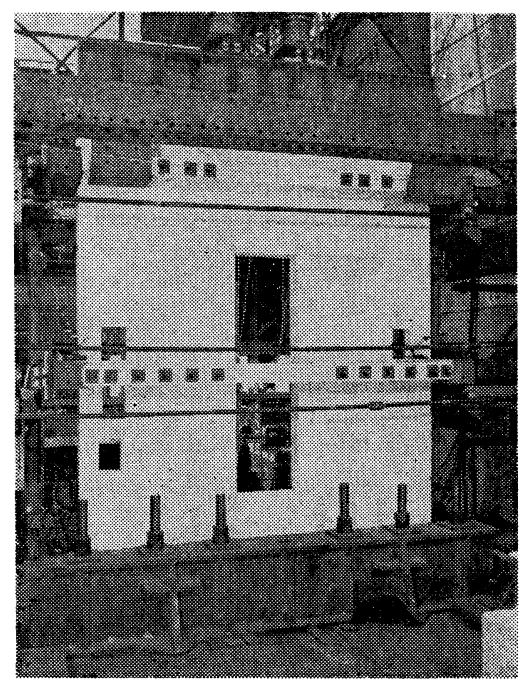

写真一5 架構模型による強度実験（実験中）

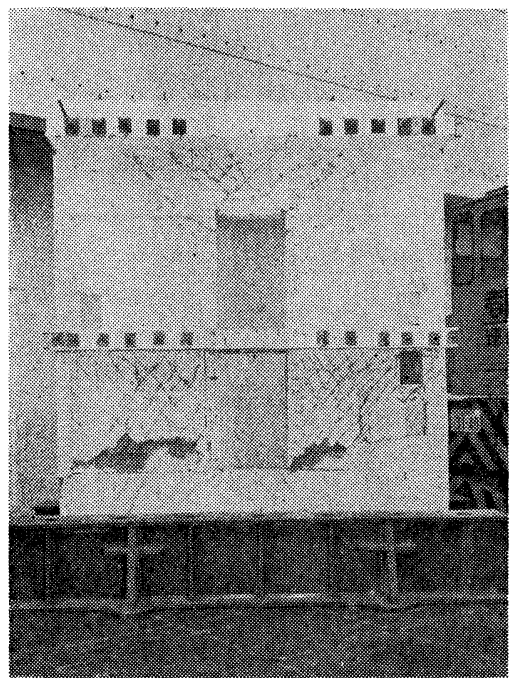

写真一6 架構模型による強度実験（完了時）

\section{（4）鉄製 shoe の設置}

実物の基礎ばりはくいで弾性支持されているので，地 震時には基礎ばりにも曲げおよびせん断応力が生ずる。 したがって供試体の基礎ばりも実験室の反力床に直接設 けず鉄製 shoe を作ってこれを介して反力をとることに した。

\section{（5）軸力の付加}

実物では大きな自重により壁柱に軸圧縮力が生じてい るが，供試体の体積は実物の $(1 / 10)^{3}$ であるため自重に よる軸圧縮力は小さい。したがって実験では供試体上部 より実物壁柱柱脚の軸応力に見合った力を $300 \mathrm{t}$ オイル ジャッキにより加えることにした。

\section{3 実験および結果}

実験は 表一3の加力サイクルによって行なわれ, 所要 日数は 5 日であった。

測定機器は, 電気式ダイヤルゲージ（ストローク 50

表一3 加カサイクルと最高荷重

\begin{tabular}{|c|c|c|c|}
\hline \multirow{2}{*}{ 加力サイクル } & 水 平 & 荷 & \multirow{2}{*}{$\begin{array}{l}\text { 備 考 } \\
\text { 設計荷重に対 } \\
\text { 站て }\end{array}$} \\
\hline & $\begin{array}{l}\text { ジャッキ荷重 } \\
P \times 2(\mathrm{t})\end{array}$ & $\begin{array}{l}\text { せん断応力度 } \\
\bar{\tau}\left(\mathrm{kg} / \mathrm{cm}^{2}\right)\end{array}$ & \\
\hline$\pm \mathrm{I}$ & $13.6 \times 2$ & 10.0 & 0.5 \\
\hline \pm II & $27.1 \times 2$ & 20.0 & 1.0 \\
\hline \pm III & $40.7 \times 2$ & 30.0 & 1.5 \\
\hline$\pm \mathrm{IV}$ & $54.2 \times 2$ & 40.0 & 2.0 \\
\hline$+\mathrm{V}$ & $67.8 \times 2$ & 50.0 & 2.5 \\
\hline$-\mathrm{V}$ & $61.0 \times 2$ & 45.0 & 2.25(破壊荷重) \\
\hline
\end{tabular}

（注） 1. $\quad \bar{\tau}=P / A_{W} \quad A_{W}$ : 有效壁柱断面積 $(12 \times 113=1356$ $\mathrm{cm}^{2}$ )

2. 実物の壁柱の設計荷重応力度 $\bar{\tau}=19.0 \mathrm{~kg} / \mathrm{cm}^{2}$ であ るがここでは便宜上 $20 \mathrm{~kg} / \mathrm{cm}^{2}$ とした。 


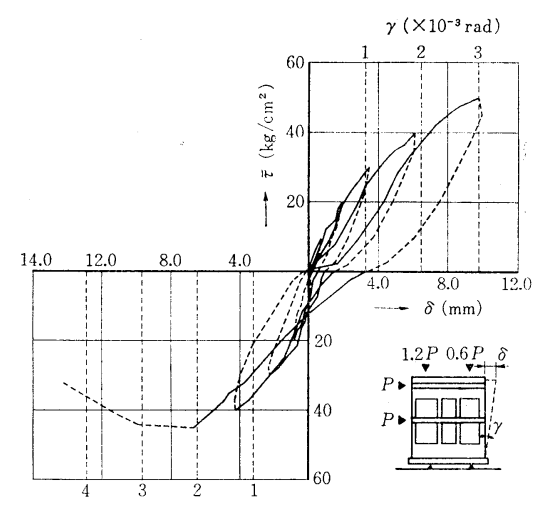

図-3 架構模型の Load-Deflection Curve

$\mathrm{mm}) 6$ 個, ワイヤストレインゲージタイプ変位計 (スト ローク $10 \mathrm{~mm}$ および $40 \mathrm{~mm}$ ) 16 個，一方向箔ひずみ ゲージ (FLA 6-11) 48 個，一方向䈾ひずみゲージを直 角に組合せたもの 15 個である。

これらの機器による測定值はデジタルストレンメータ とテープさん孔器に記録させ, 電算機で処理した。

実験の結果を図一3に示す。また結論を報告書より転 記すると，

（1）設計荷重までは, 荷重一変形関係はほぼリニア 一であり,きわめて安定していた。

（2）設計荷重を越えても，応力的には約 2 倍の $\bar{\tau}=$ $40 \mathrm{~kg} / \mathrm{cm}^{2}$, 変形的には約 5 倍の部材角 $\left(2.5 \times 10^{-3}\right)$ ま で安全に耐え得ることが判明した。

（3）これを解析結果より判定すると, 静的には 1.2 $\mathrm{g}$ の水平力, 動的には $700 \mathrm{gal}$ 以上の人工地震波に対し ても安全であることが判明した。

\section{3. 場所打ちコンクリートぐいの載荷試験}

\section{1 概 要}

最高裁判所の建物群は, ベノト工法による場所打ちコ ンクリートぐいとプレストレストコンクリートぐい（高 温高圧養生くい,事務棟に使用）により支持されている。

場所打ちコンクリートぐいは, 径 $1000 \mathrm{~mm}, 1200 \mathrm{~mm}$ の 2 種類で総計約 572 本であり, GL $-30 \mathrm{~m}$ 付近の $N$ 值 50 以上の東京碗層に支持されている (図一5 参照)。 設計值は長期許容支持力をそれぞれ $250 \mathrm{t}, 360 \mathrm{t}$ として いる。

試験要領は次の各項および 図一4, 表一4 による。

試験ぐい 径 $1000 \mathrm{~mm}$, 長さ $29 \mathrm{~m} 500$, 実験專用ぐ い

方 法 鉛直載荷 $800 \mathrm{t}, 100 \mathrm{t}$ 刻み増繰返し 8 サイ
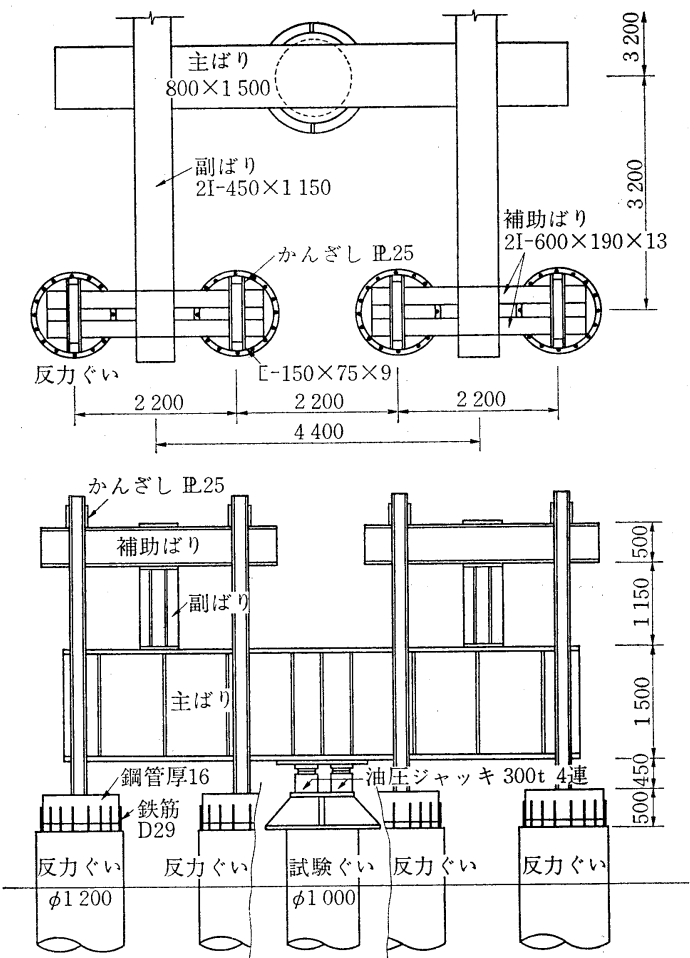

図一4 く(載荷試験機構説明図

クルとし，詳細は土質工学会の方法 (1971) による。

反 力 隣接くい 8 本使用

加 力 電動油圧ジャッキ $300 \mathrm{t} 4$ 連

測 定 載荷部分における通常の変位測定と共に二 重管式沈下計によりくい先端および中央部 の沈下量測定，くい体に設けた 10 対の鉄 筋計による荷重伝達量の測定

\section{2 載荷装置の check}

図一4 に示すように，300 t-4 連ジャッキによる反力 は，主ばり，副ばり，補助ばりを経て，8本（4本 2 列) の反力ぐいに伝えられる。以下に check の概要を示すと

(1) 主ばりの check

断面 $800 \times 1500$ III型

$$
J_{x}=5.95 \times 10^{6} \mathrm{~cm}^{4} \quad Z_{x}=79260 \mathrm{~cm}^{3}
$$

荷重 $800 \mathrm{t}$

$$
\begin{aligned}
& M=P l / 4=800 \times 440 / 4=88000 \mathrm{t}-\mathrm{cm} \\
& \sigma=M / Z_{x}=88000 / 79200=1.11 \mathrm{t} / \mathrm{cm}^{2} \\
& \quad<2.1 \mathrm{t} / \mathrm{cm}^{2} \text { O.K. }
\end{aligned}
$$

たわみ

$$
\begin{aligned}
\delta= & 800 \times 10^{3} \times 440^{3} / 48 \times 2.1 \times 10^{6} \times 5.95 \times 10^{6} \\
& =0.114 \mathrm{~cm} \fallingdotseq l / 3860 \text { O.K. }
\end{aligned}
$$

副ばり, 補助ばりの check も同様なので省略 
表一4 くい載荷試験における測定計器一覧表

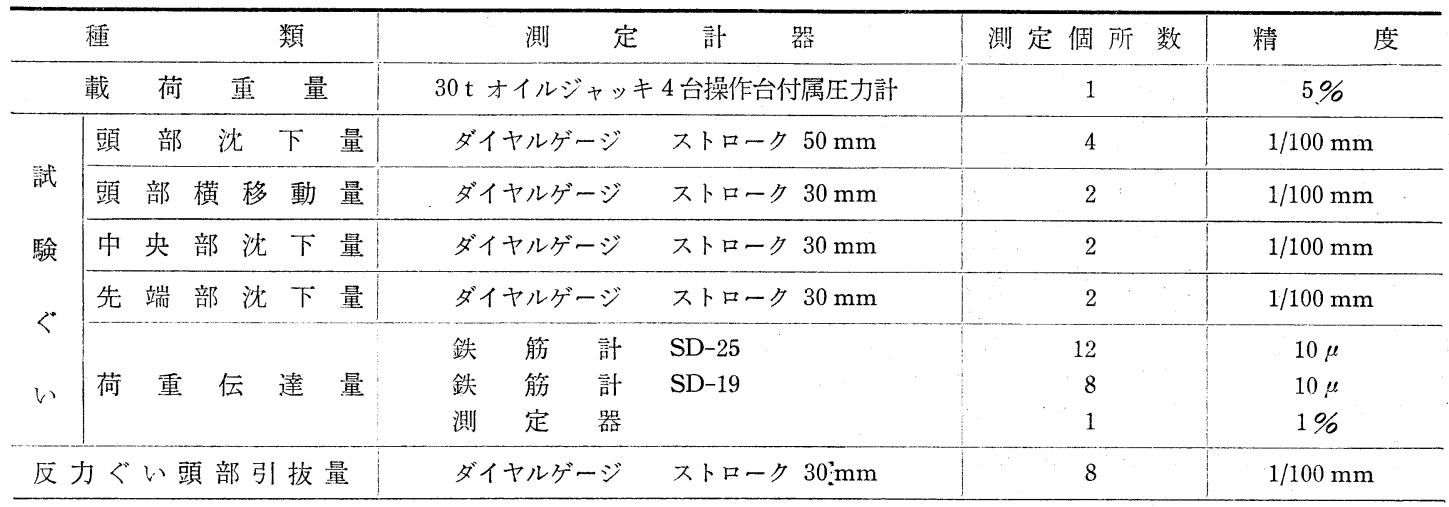

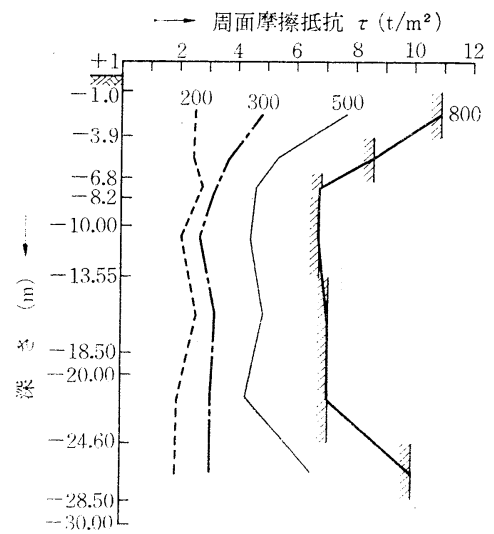

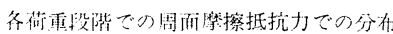

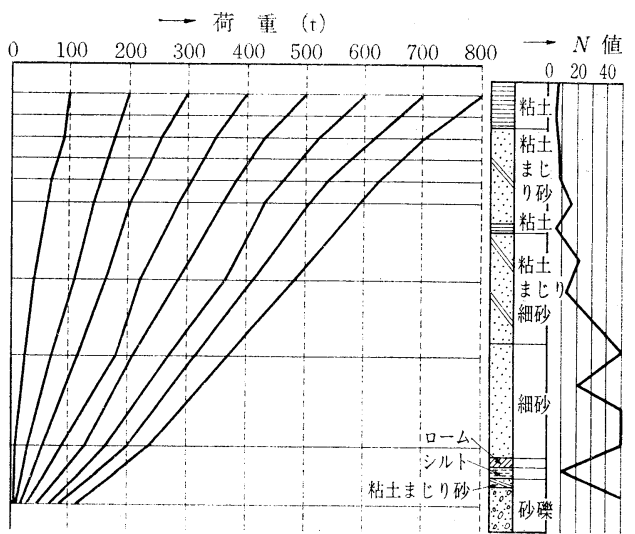

荷重の伝泚状況

図一5 鉄筋計等による測定結果

\section{（2）反カぐい鉄筋とリングの取合い部分}

く、鉄筋 16-D 29, 断面積 $\mathrm{A}=16 \times 6.41=102.56 \mathrm{~cm}^{2}$ 耐力 $102.56 \times 3=307.68 \mathrm{t}>800 / 8 \mathrm{t}$ O.K.

溶接長 $5 \mathrm{~cm} \quad P=100 / 16=6.25 \mathrm{t} /$ 本

$$
\begin{aligned}
\sigma & =0.707 \times P / s \cdot l=0.707 \times 6.25 / 1.2 \times 0.7 \times 5 \\
& =1.05 \mathrm{t}<1.2 \mathrm{t} \text { O.K. }
\end{aligned}
$$

上記のように溶接長 $5 \mathrm{~cm}$ で安全であるが，念のため 溶接長 $10 \mathrm{~cm}$ で施工した。しかしこれでも荷重が 800 $\mathrm{t}$ 近くになると時々鋭い音を溶接部位より発し，驚かさ れることがあった。

\section{(3) 反カぐいの check}

反力ぐいは本ぐいであるから，その意味での安全性を 計算で確かめると共に, 試験中もゲージを設けて常に監 視を行なった。(結果は $0.5 \mathrm{~mm}$ 以下の浮上り量で納ま った。)

\section{3 試 験 結 果}

くい頭部の荷重-沈下曲線は最大荷重 $800 \mathrm{t}$ までなだ らかな曲線となっており, 沈下量もきわめて小さく 800 $\mathrm{t}$ 載荷時で $11.3 \mathrm{~mm}$ であった。(このとき先端は 3.6 $\mathrm{mm}$ )

降伏点は $\log P-\log S$ 曲線, $S-\log t$ 曲線, $\Delta S / \log$ $\left(t_{2}-t_{1}\right)-P$ 曲線のいずれの曲線から む載荷荷重内では 認められず， $800 \mathrm{t}$ 以上であると判定された。

したがって本試験のくいは長期設計耐力 $250 \mathrm{t}$ ，短期 設計耐力 $500 \mathrm{t}$ に対して十分安全である。

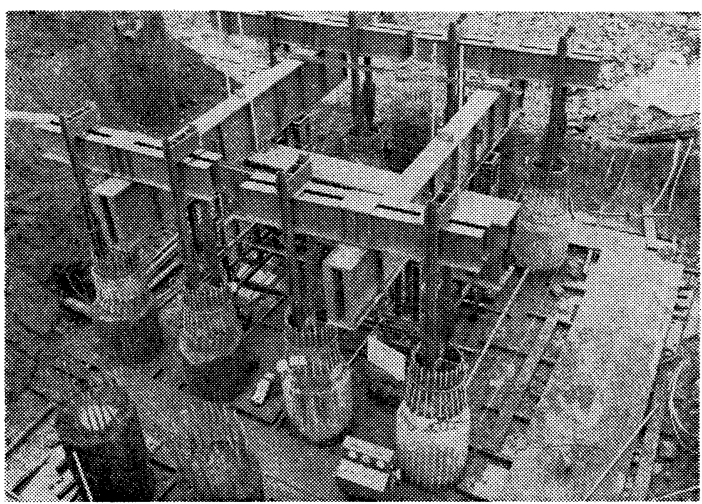

写真一7 くい載荷試験（全景） 


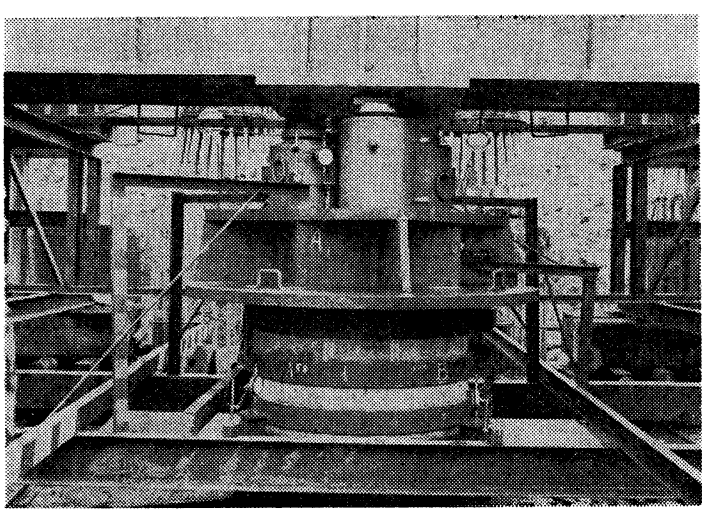

写真一8 くい載荷試験（試験ぐい柱頭）

柱頭のキャッピングは型わくを用いて早強コンクリー

卜を打設し，表面は左官仕上げにより水平に製作した。

と報告された。

なお，図一5 はくい体に設けられた鉄筋計による測定 結果を示したものである。

4. 場所打ちコンクリートぐいの水平交番 載荷試験

\section{1 概 要}

くいに曲げ応力を負担させる設計となっている個所が ある。先に鉛直載荷に用いた試験ぐいを使って，くい頭 に水平力を交番に加えて, くい及び地盤の力学的性状を 試験した。試験ぐいは前節で報告したとおり，800 t 載 荷があったといっても何ら損傷のない健全なくいであっ た。

試験要領は次の各項および図一6による。

試験ぐい $800 \mathrm{t}$ 鉛直載荷試験ぐいと同じ

方 法 最大 $90 \mathrm{t}$ 交番加力, $\pm 20, \pm 40, \pm 50,+$ $89 \mathrm{t}$ の 4 サイクル

反 力 隣接ぐい 8 本使用
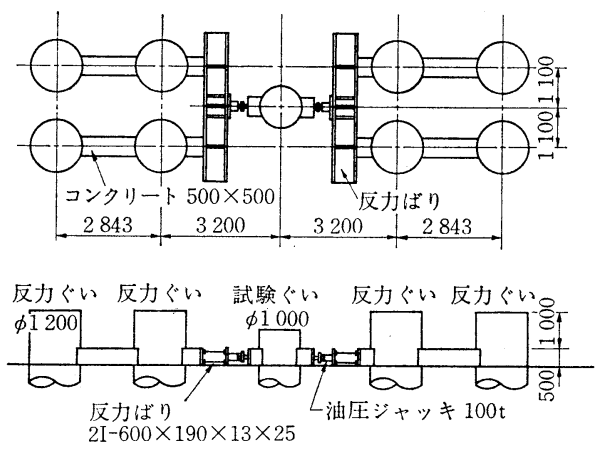

図一6 く(水平交番載荷試験機構説明図
加 力 $100 \mathrm{t}$ 油圧ジャッキ1対, 手動操作

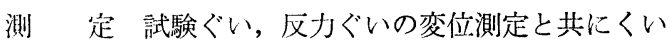
体の各部位のひずみを埋込み鉄筋計 $(10$ 対）にて測定

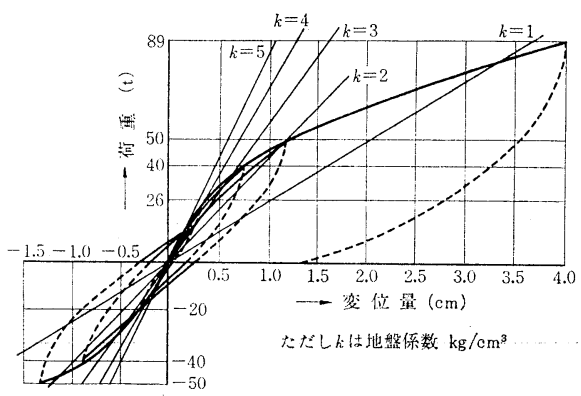

図一7 くい頭部の Load-Deflection Curve

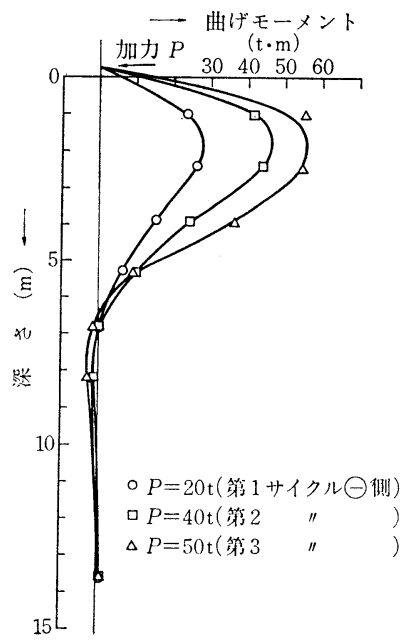

(a)

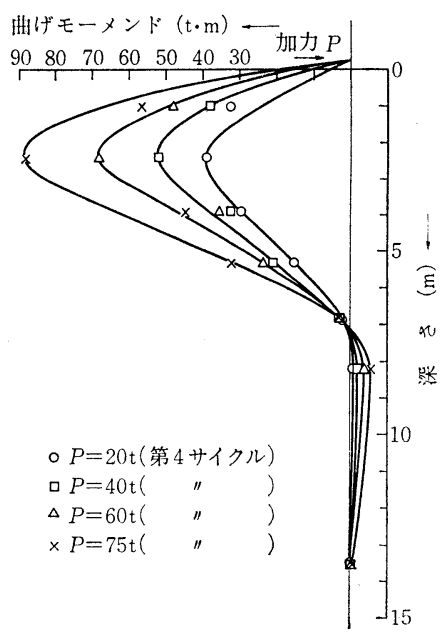

(b)

図一8 くいの曲げモーメント分布 


\section{2 試験 結 果}

報告書より試験結果を転記すると下記のとおりであ る。

（1）〈い頭部の荷重-変位曲線を 図一7 に示す。こ の図中 Chang の方法による荷重一変位関倸を地盤係数 $k$ をパラメーターにして直線で示してある。くい頭部自由 の場合の水平方向バネ定数は $50 \mathrm{t}$ 載荷時まで $K=42.4$ $\mathrm{t} / \mathrm{cm}$ となる。

（2）曲げモーメントの分布曲線を 図一8 (a), (b) に 示す。曲げモーメントの最大值は試験地盤 $\mathrm{GL}-2.5 \mathrm{~m}$ 付近にあり, 曲げモーメントの零となる点は荷重の大小 に関倸なく一定である。

\section{5.あとがき}

以上に，本工事に括ける試験の二，三について報告し たが，この工事では上記のほかに外壁の石張りを対象と した数多くの施工実験, 照明・音響の効果の実験等が行 なわれ，各施工はそれぞれ，それらの実験をうらゔけと して、「石橋をたたくように」慎重に進められたもので ある。勿論, 建築工事は本工事に限らず 1 件ごとにそれ ぞれの苦労があるが, 本工事ではその規模の大きさのた め普通の工事の経験がそのまま適用できることに自信が なかった，そのためこのような初心に戻るような実験を してのち施工といらことになった次第である。これが副 次的に工事全体の管理上にもよかったと信じている。
なお，蛇足ながら「施工詳細の施工規模に対する scale effect」というものについて，興味ある問題が多い と感じさせられた工事であった。

終わりに概要を記しておく。

$\begin{array}{lc}\text { 工事名称 } & \text { 最高裁判所庁舎建築工事 } \\ \text { 所 在 地 } & \text { 東京都干代田区集町 } 4-2 \\ \text { 工 期 } & \text { 昭和 } 46 \text { 年 } 6 \text { 月 } 9 \text { 日 昭和 } 49 \text { 年 } 3 \text { 月 } 25 \text { 日 } \\ \text { 敷地面積 } & 37427 \mathrm{~m}^{2} \\ \text { 建築面積 } & 18075446 \mathrm{~m}^{2} \\ \text { 延べ面積 } & 59588744 \mathrm{~m}^{2}\end{array}$

\section{延べ面積内訳}

\begin{tabular}{|c|c|c|}
\hline 法廷棟（大） & $\begin{array}{l}\text { 鉄簲コン階 地上 } 5 \text { 階一部鉄骨造 } \\
\end{array}$ & $\begin{array}{r}\left(\mathrm{m}^{2}\right) \\
11262979 \\
\end{array}$ \\
\hline 法廷棟 (小) & $\begin{array}{l}\text { 釷筋コンクリート造 } \\
\text { 階 地上 } 4 \text { 階 }\end{array}$ & 5504561 \\
\hline 因書館棟 & 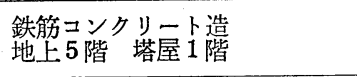 & 7296685 \\
\hline 裁判棟（東） & $\begin{array}{l}\text { 鉄骨鉄篗コンクリート造 } \\
\text { 堦屋 } 1 \text { 階 }\end{array}$ & 9877068 \\
\hline 裁判棟 (北) & 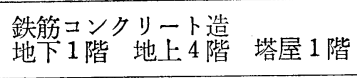 & 8724972 \\
\hline 事務棟 & $\begin{array}{l}\text { 鉄筋コンクリート造 } \\
\text { 塔屋 } 1 \text { 階 }\end{array}$ & 16922479 \\
\hline & 計 & 59588744 \\
\hline
\end{tabular}

\section{主要室大きさと天井高}

大法廷

$23.50 \mathrm{~m} \times 23.05 \mathrm{~m}$ 天井高 $8.0 \mathrm{~m}$ (中央シリンダー天井部 $23 \mathrm{~m} \sim 28 \mathrm{~m}$ )

小法廷 $17.50 \mathrm{~m} \times 15.50 \mathrm{~m} \quad 6.55 \mathrm{~m} \times 8.3 \mathrm{~m}$ 大ホール $45.825 \mathrm{~m} \times 18.00 \mathrm{~m}$ $17.0 \mathrm{~m} \sim 23.35 \mathrm{~m}$ 公衆控室 裁判官室
$17.50 \mathrm{~m} \times 25.00 \mathrm{~m}$

$12.125 \mathrm{~m} \times 7.05 \mathrm{~m}$
$12.60 \mathrm{~m} \sim 13.60 \mathrm{~m}$ $2.8 \mathrm{~m}$

\title{
SOME TESTS CONDUCTED IN CONNECTION WITH THE CONSTRUCTION OF THE SUPREME COURT BUILDINGS
}

\author{
By Sadao KIMURA ${ }^{11}$
}

Concrete Journal, Vol. 13, No. 1, pp. 30 37 (1975)

\section{Summary}

The construction work of the new buildings of the Supreme Court was one of the largest in scale carried out in this land in the recent years. Because of its gigantic scale and mass, numerous and various tests on materials and members were carried out prior to the initiation of the undertaking. Among these, reports are herewith summarized on the followings :

1. Test of shear strength of the building frame by mini-scale model.

2. Loading test (vertical) of cast-in-place reinforced concrete pile.

3. Loading test (horizontal) of an identical east-in-place reinforced concrete pile.

1) Deputy Head of the Supervision Division, Goverment Buildings Depertment, Ministry of Construction 